\title{
PENGEMBANGAN FITUR E-MATUR DENGAN V-MODEL SEBAGAI ALAT PENGADUAN PUBLIK UNTUK WEBSITE BADAN KEPEGAWAIAN NEGARA
}

\author{
Admaja Dwi Herlambang ${ }^{1}$, Aditya Rachmadi ${ }^{2}$ Kartika Utami ${ }^{3}$, Rahmana Ilmi Hakim ${ }^{4}$, Nurur Rohmah ${ }^{5}$ \\ 1,2,3,4 Jurusan Sistem Informasi, Fakultas Ilmu Komputer, Universitas Brawijaya (10pt) \\ Email: ${ }^{1}$ herlambang@ub.ac.id, ${ }^{2}$ rachmadi.aditya@ub.ac.id, ${ }^{3}$ kartika.libra@gmail.com, \\ 4ilmi.rahmana@gmail.com, ${ }^{5}$ nururrohmah23@gmail.com
}

(Naskah masuk: 01 Desember 2018, diterima untuk diterbitkan: 07 Januari 2019)

\begin{abstract}
Abstrak
Bagian Informasi Kepegawaian dan Komunikasi merupakan sebuah divisi yang ada pada Kantor Regional II Badan Kepegawaian Negara Surabaya. Layanan pengaduan publik oleh Bagian Informasi Kepegawaian dan Komunikasi melalui website memerlukan fitur pengelolaan. Penelitian pengembangan ini menggunakan metode V-Model. Proses pengujian yang dilakukan meliputi unit testing, integration testing, system testing, dan acceptance testing. Unit testing dilakukan dengan basis path testing dan menghasilkan 4 independent path dari perhitungan cyclomatic complexity pada kasus uji unit addPIC. Integration testing pada kasus uji fungsi addPIC dari class controller admController dengan fungsi insertPIC dari class model admModel menunjukkan hasil valid. System testing dilakukan terhadap 28 fungsi pada sistem, yang menunjukkan hasil valid. Acceptance testing dilakukan terhadap stakeholder atau user menggunakan black box testing menunjukkan hasil bahwa stakeholder menerima fungsi dalam sistem yang dibuat dan telah sesuai dengan kebutuhan fungsional pada dokumen elisitasi kebutuhan sistem.
\end{abstract}

Kata kunci: layanan pengaduan publik, pengembangan, v-model, website

\section{E-MATUR DEVELOPMENT USING V-MODEL AS PUBLIC COMPLAINT FEATURE FOR STATE STAFFING AGENCY WEBSITE}

\begin{abstract}
Staff Information and Communication Division is one of division in State Staffing Agency Regional Office II Surabaya. Public complaint service handled by Staff Information and Communication Division through website require management features. This development research used $V$-Model method. The testing process includes unit testing, integration testing, system testing, and acceptance testing. Unit testing used the base path testing that produces 4 independent paths from the calculation of cyclomatic complexity in the addPIC unit test case. Integration testing in the test case of the addPIC function from controller class admController with the insertPIC function from model class admModel shows valid results. System testing performed on the 28 system functions show a valid result. Acceptance testing conducted against stakeholders or users using black box testing indicates that the stakeholders have received the system functions and had been in accordance with the functional requirements that exist in the document elicitation system requirements.
\end{abstract}

Keywords: public complaint service, development, v-model, website

\section{PENDAHULUAN}

E-Government menjadi sangat populer sejalan dengan perkembangan teknologi informasi dan komunikasi. Berbagai lembaga pemerintahan berlomba untuk mengimplementasikan $E$ Government dengan strategi yang disesuaikan dengan kondisi masing-masing. Kantor Regional II Badan Kepegawaian Negara Surabaya merupakan sebuah instansi pemerintahan yang mengelola administrasi dalam bidang kepegawaian.
Penerapan E-Government di dalam Kantor Regional II Badan Kepegawaian Negara Surabaya dalam pengembangannya dengan sistem pelayanan publik belum dapat dilakukan secara maksimal. Pada website tersebut terdapat fitur konsultasi yang menunjukkan jumlah pegawai yang telah melakukan konsultasi atau keluhan hanya dibagikan dan ditampung dalam halaman website namun konsultasi atau keluhan yang telah disampaikan belum tentu diproses oleh pihak pelayanan informasi Kantor Regional II Badan Kepegawaian Negara Surabaya. 
Kelebihan penggunaan sistem informasi dalam konsultasi diantaranya yaitu dapat memberikan dampak kemudahan bagi kepala BKBH untuk dapat melakukan pemantauan terhadap data konsultasi yang dilakukan oleh pengguna secara online (Handoko, Lestariningsih, \& Ardhianto, 2014).

System Development Life Cycle (SDLC) atau SDLC adalah sebuah kerangka kerja terstruktur yang terdiri dari proses sekuensial untuk pengembangan sistem informasi. SDLC juga dapat diartikan sebagai rangkaian aktivitas yang dilakukan oleh profesional dan pengguna sistem untuk mengembangkan dan mengimplementasikan sistem (Turban \& Volonino, 2011). V-Model merupakan perluasan dari model waterfall dalam proses pengembangan perangkat lunak. V-Model menggambarkan hubungan dari aksiaksi jaminan kualitas dengan komunikasi, pemodelan, dan aktivitas-aktivitas konstruksi pada tahap awal. Fase pada sisi kiri V-Model bergerak ke bawah untuk melakukan spesifikasi kebutuhan, menyaring dasar masalah untuk menghasilkan solusi dengan progresif, semakin detail dan teknis. Saat kode program telah dibuat, maka fase bergerak ke atas menuju sisi kanan V-Model (Pressman, 2010).

Terdapat 9 fase dalam V-Model. Fase pertama adalah fase Requirement Modelling yaitu tahap mendefinisikan rencana sistem atau perangkat lunak. Architectural Design digunakan untuk memahami dan merancang desain arsitektur sistem. Component Design, desain sistem dibagi menjadi beberapa modul yang lebih kecil. Code Generation mengimplementasikan desain penyimpanan sistem dan setiap modul yang telah dibangun dalam pengkodean. Executable Software (Implementation) dilakukan pengimplementasian terhadap keseluruhan sistem setelah pengkodean (coding) selesai dilakukan. Unit Testing, pengujian dilakukan untuk mencari kesalahan akibat salah tulis atau kesalahan pemrograman yang disebut dengan debugging. Integration Testing melakukan pengujian terhadap kumpulan modul yang telah diintegrasikan menjadi beberapa subsistem. System Testing dilakukan pengujian terhadap seluruh sistem atau perangkat lunak apakah integrasi pada antar modul sistem telah berjalan dengan baik. Acceptance Testing bertujuan untuk menguji apakah user telah menerima sistem yang dibangun dilihat dari requirement yang telah dipenuhi dan kemudahan penggunaan sistem. Jika terdapat kekurangan pada sistem, maka dapat dilakukan iterasi pada siklus hidup sistem (Nurbaity, 2010).

\section{METODOLOGI}

Tahapan penelitian disajikan pada Gambar 1 . Tahapn penelitian disesuaikan dengan tahapan yang dilalui dalam V-Model.

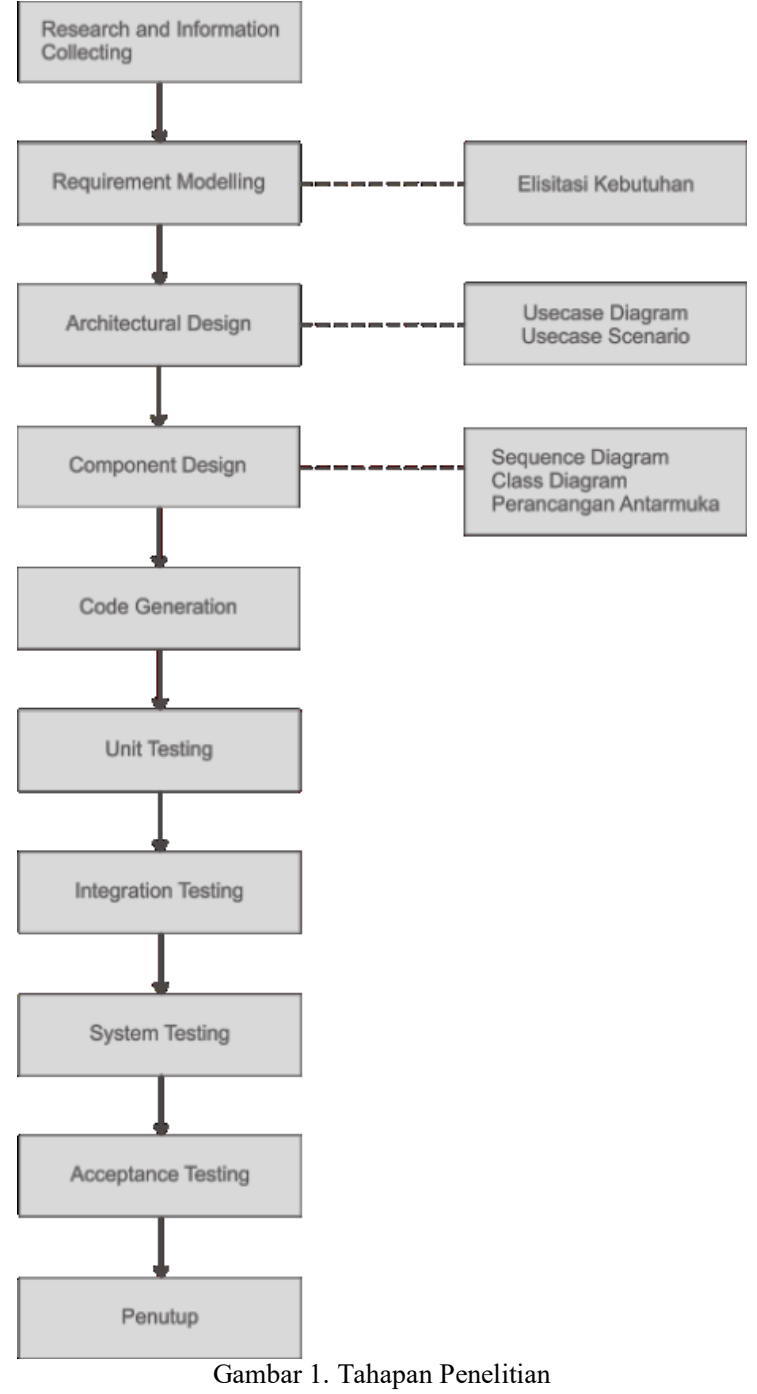

\subsection{Research and Information Collecting}

Tahap ini bertujuan untuk mengumpulkan informasi mengenai metode yang digunakan pada penelitian baik itu melalui buku, jurnal, website maupun sumber lainnya. Referensi pada penelitian ini yaitu mengenai V-Model yang berperan sebagai metode dalam pengembangan sistem informasi, dan Research \& Development sebagai metode dalam penulisan laporan penelitian. Terdapat jurnal yang menjadi referensi mengenai metode pada penelitian ini yang berjudul Research and Development (R\&D) Sebagai Salah Satu Model Penelitian Dalam Bidang Pendidikan oleh Wingate (2015). Wingate (2015) membahas secara singkat tentang metode penelitian dan pengembangan (R\&D) serta tahapan yang harus dilakukan dan juga model yang dihasilkan pada setiap tahap. Research and information collecting meliputi studi literatur yang berkaitan dengan permasalahan yang dikaji, pengukuran kebutuhan, penelitian dalam skala kecil, dan persiapan untuk melakukan perumusan kerangka kerja penelitian (Wingate, 2015). 


\subsection{Requirement Modelling}

Proses identifikasi masalah dibutuhkan untuk mendukung data dalam penelitian. Data ini merupakan data dari hasil wawancara dengan bagian informasi kepegawaian di Kantor Regional II Badan Kepegawaian Negara yang berperan sebagai narasumber atau stakeholder dari sistem yang dibangun. Wawancara ini dilakukan untuk mengidentifikasi kebutuhan fungsional sistem, kemudian hasilnya akan disusun menjadi dokumen elisitasi kebutuhan sistem dimana berisi kebutuhan sistem sesuai keinginan stakeholder dan kebutuhan sistem yang telah disarankan oleh peneliti sebagai solusi dari permasalahan.

\subsection{Architectural Design}

Hasil dari elisitasi kebutuhan sistem akan diterjemahkan ke dalam use case diagram yang bertujuan untuk memberikan gambaran bagaimana pengguna sistem dapat berinteraksi dengan sistem. Setelah use case dibuat, selanjutnya akan dibuat use case scenario yang digunakan untuk menjabarkan atau menjelaskan alur kerja dari setiap use case pada use case diagram

\subsection{Component Design}

Hasil dari transformasi use case diagram menjadi use case scenario akan digunakan untuk membuat sequence diagram yang menjelaskan bagaimana alur dari fungsi sistem yang akan dibangun. Sequence diagram ini menunjukkan bagaimana pesan yang dikirimkan pada setiap objek untuk menyelesaikan fungsi sistem. Selain itu, pada tahap ini juga dijelaskan mengenai desain arsitektur database yang akan didefinisikan dalam bentuk class diagram.

\subsection{Code Generation}

Sistem atau perangkat lunak akan dibangun berbasis website dan berdasarkan pada desain arsitektur yang telah didefinisikan sebelumnya. Pada tahap implementasi sistem dilakukan menggunakan pemrograman berorientasi objek dengan bahasa pemrograman PHP dan manajemen basis data sistem MySQL.

\subsection{Unit Testing}

Pada sistem yang telah diimplementasikan, selanjutnya akan dilakukan unit testing dengan basis path testing yang bertujuan untuk menguji batasan dan jalur independen pada setiap unit program menggunakan logika pemrograman.

\subsection{Integration Testing}

Pengujian dilakukan terhadap setiap modul yang telah diintegrasi menjadi subsistem-subsistem. Pengujian integrasi dikonsentrasikan untuk mendeteksi kesalahan atau ketidaksesuaian antarmuka atau keluaran dari setiap modul yang telah diintegrasi ke dalam sistem.

\subsection{System Testing}

Tahap ini pengujian dilakukan terhadap sistem atau perangkat lunak yang telah dibangun menggunakan validation testing yang bertujuan untuk memastikan setiap fungsi sistem telah sesuai dengan spesifikasi kebutuhan sistem.

\subsection{Acceptance Testing}

Tahap ini pengujian dilakukan terhadap sistem oleh stakeholder atau penanggung jawab sistem yaitu bagian Informasi Kepegawaian Kantor Regional II Badan Kepegawaian Negara Surabaya untuk mengetahui apakah sistem yang dibuat telah sesuai dengan kebutuhan pengguna pada tahap requirement modelling. Apabila sistem yang dibangun telah lolos acceptance testing ini, maka pengembangan sistem yang dilakukan telah dinyatakan selesai.

\section{ANALISIS DAN PERANCANGAN}

\subsection{Analisis Kebutuhan}

Dari hasil proses elisitasi kebutuhan perangkat lunak melalui proses wawancara dengan pihak Kantor Regional II Badan Kepegawaian Negara dihasilkan final draft elisitasi kebutuhan perangkat lunak sebagai dasar pada pembuatan sistem, selain itu juga terdefinisi 4 aktor yang memiliki peran dalam sistem yaitu admin, PIC, agen, dan klien.

Kebutuhan perangkat lunak yang terdefinisi dari hasil analisis dan spesifikasi kebutuhan yaitu terdapat 28 kebutuhan fungsional, 1 kebutuhan nonfungsional, dan 28 fitur sistem. Pada Tabel 1 disajikan daftar fungsi-fungsi yang harus ada dan telah disesuaikan dengan kebutuhan sistem yang sudah diidentifikasi sebelumnya.

Gambar 2 merupakan use case diagram dari hasil analisis kebutuhan sistem E-matur. Use case diagram di atas menggambarkan fungsional dari sistem yang dibangun dan identifikasi aktor yang berinteraksi menjalankan sistem. Setiap use case yang telah didefinisikan, memiliki scenario atau penjelasan mengenai kondisi yang harus dipenuhi sebelum atau sedang menjalankan use case, alur kerja aktor dengan sistem, dan kondisi setelah use case selesai dilakukan. Berikut merupakan use case scenario menambah data PIC yang dituangkan dalam Tabel 2.

\subsection{Perancangan Sistem}

Perancangan sistem bertujuan agar sistem yang dibangun sesuai dengan kebutuhan pengguna. Perancangan sistem ini menggunakan diagram UML

(Unified Modeling Language). Gambar 3 merupakan pemodelan class diagram sistem E-matur yang berisi penggambaran relasi antar kelas admController, admModel, admView, picController, picModel, picView, agnController, agnModel, dan agnView 
Tabel 1. Kebutuhan dari Sistem

\begin{tabular}{|c|c|}
\hline Kode Fungsi & Nama Fungsi \\
\hline$E M-F-001$ & Melihat Dashboard \\
\hline$E M-F-002$ & Melihat Data Konsultasi \\
\hline$E M-F-003$ & Melihat Detail Data Konsultasi \\
\hline$E M-F-004$ & Menambah Data Konsultasi \\
\hline$E M-F-005$ & Menghapus Data Konsultasi \\
\hline$E M-F-006$ & Melihat Data Personal In Charge \\
\hline$E M-F-007$ & Menambah Data Personal In Charge \\
\hline$E M-F-008$ & Menghapus Data Personal In Charge \\
\hline$E M-F-009$ & Memperbarui Data Personal In Charge \\
\hline$E M-F-010$ & Melihat Data Agen \\
\hline$E M-F-011$ & Menambah Data Agen \\
\hline$E M-F-012$ & Menghapus Data Agen \\
\hline$E M-F-013$ & Memperbarui Data Agen \\
\hline$E M-F-014$ & Melihat Data Rekap Kinerja Agen \\
\hline$E M-F-015$ & Menghapus Data Rekap Kinerja Agen \\
\hline$M-F-016$ & Mencetak Data Rekap Kinerja Agen \\
\hline$E M-F-017$ & $\begin{array}{l}\text { Melihat Data Rekap Kinerja Personal In } \\
\text { Charge }\end{array}$ \\
\hline$E M-F-018$ & $\begin{array}{l}\text { Menghapus Data Rekap Kinerja Personal In } \\
\text { Charge }\end{array}$ \\
\hline$E M-F-019$ & $\begin{array}{l}\text { Mencetak Data Rekap Kinerja Personal In } \\
\text { Charge }\end{array}$ \\
\hline$E M-F-020$ & Melihat Data Rekap Kinerja Admin \\
\hline$E M-F-021$ & Mencetak Data Rekap Kinerja Admin \\
\hline$E M-F-022$ & Memperbarui Profil Admin \\
\hline$E M-F-023$ & Memperbarui Profil Agen \\
\hline$E M-F-024$ & Memperbarui Profil Personal In Charge \\
\hline$E M-F-025$ & Melakukan disposisi Pesan Konsultasi \\
\hline$E M-F-026$ & Menjawab Pesan Konsultasi \\
\hline$E M-F-027$ & Mengubah Disposisi Pesan Konsultasi \\
\hline$E M-F-028$ & Mencari Data Konsultasi \\
\hline
\end{tabular}

Tabel 2 Use Case Scenario Menambah Data PIC

\begin{tabular}{|c|c|}
\hline Item & Deskripsi \\
\hline Aktor & Admin \\
\hline Use Case & Menambah Data PIC \\
\hline Deskripsi & $\begin{array}{l}\text { Admin dapat menambahkan data PIC (Personal } \\
\text { In Charge) ke dalam database. }\end{array}$ \\
\hline Pra-Kondisi & Admin telah login ke sistem \\
\hline \multirow[t]{11}{*}{ Tindakan } & Admin memilih menu Pengaturan PIC \\
\hline & $\begin{array}{l}\text { 2. Sistem melakukan permintaan halaman } \\
\text { data PIC (Personal In Charge) }\end{array}$ \\
\hline & Admin memilih menu Tambah PIC \\
\hline & $\begin{array}{l}\text { 4. Sistem melakukan permintaan ke } \\
\text { formulir tambah PIC }\end{array}$ \\
\hline & 5. Admin mengisi formulir berisi Nama \\
\hline & Lengkap, NIP, Jabatan, Kata Sandi, dan \\
\hline & 6. Admin memilih tombol Tambah \\
\hline & 7. Sistem melakukan permintaan untuk \\
\hline & $\begin{array}{l}\text { menyimpan data PIC baru ke dalam } \\
\text { database }\end{array}$ \\
\hline & Sistem menampilkan halaman data PIC \\
\hline & $\begin{array}{l}\text { (Personal In Charge) dan memuat data } \\
\text { PIC yang baru ditambahkan }\end{array}$ \\
\hline Post-Kondisi & Sistem menampilkan halaman data PIC \\
\hline & (Personal In Charge) dan memuat data PIC \\
\hline & \\
\hline Alternatif & - \\
\hline
\end{tabular}

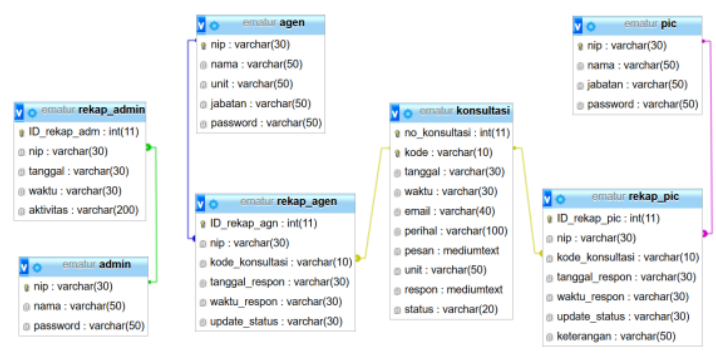

Gambar 4. Physical Data Diagram

Gambar 4 merupakan diagram perancangan data yang menunjukkan relasi relasi antar tabel. Terdapat 7 tabel antara lain konsultasi, admin, rekap_admin, pic, rekap_pic, agen, dan rekap_agen. Pada relasi tabel ini, tabel admin dan rekap admin dihubungkan oleh nip admin, tabel agen dan rekap_agen dihubungkan oleh nip agen, tabel pic dan rekap_pic dihubungkan oleh nip pic, tabel konsultasi dan rekap_agen dihubungkan oleh kode konsultasi, tabel konsultasi dan rekap_pic dihubungkan oleh kode konsultasi.

Gambar 5 menunjukkan interaksi antar objek ketika sistem menjalankan proses untuk menambah data PIC yang digambarkan ke dalam Sequence Diagram. Dimulai dari admin sebagai user sistem mengklik menu Pengaturan PIC untuk meminta halaman data PIC (Personal In Charge) pada view. Kemudian user mengklik tombol Tambah PIC untuk meminta halaman tambah data PIC (Personal In Charge) pada view. Selanjutnya admin mengisi Nama, NIP, Jabatan, Kata Sandi, dan Konfirmasi Kata Sandi, serta mengklik tombol Tambah untuk menyimpan data PIC pada database. Kemudian controller menjalankan fungsi addPIC dengan parameter nip, nama, jabatan dan pass yang didalamnya memanggil fungsi insertPIC dengan parameter nip, nama, jabatan dan password pada model untuk menyimpan data PIC (Personal In Charge) yang ditambahkan. Setelah model menyimpan data PIC (Personal In Charge) pada database, maka seluruh data PIC (Personal In Charge) ditampilkan kembali ke view melalui controller.

Gambar 6 merupakan implementasi tampilan sistem dalam melakukan penambahan data PIC oleh admin. Terdapat sebuah form data PIC yang dibutuhkan diantaranya nama lengkap, NIP, unit kerja, jabatan, kata sandi, dan konfirmasi kata sandi yang ditampilkan dengan model pop up di atas halaman daftar data PIC yang sudah terdaftar. 
ue

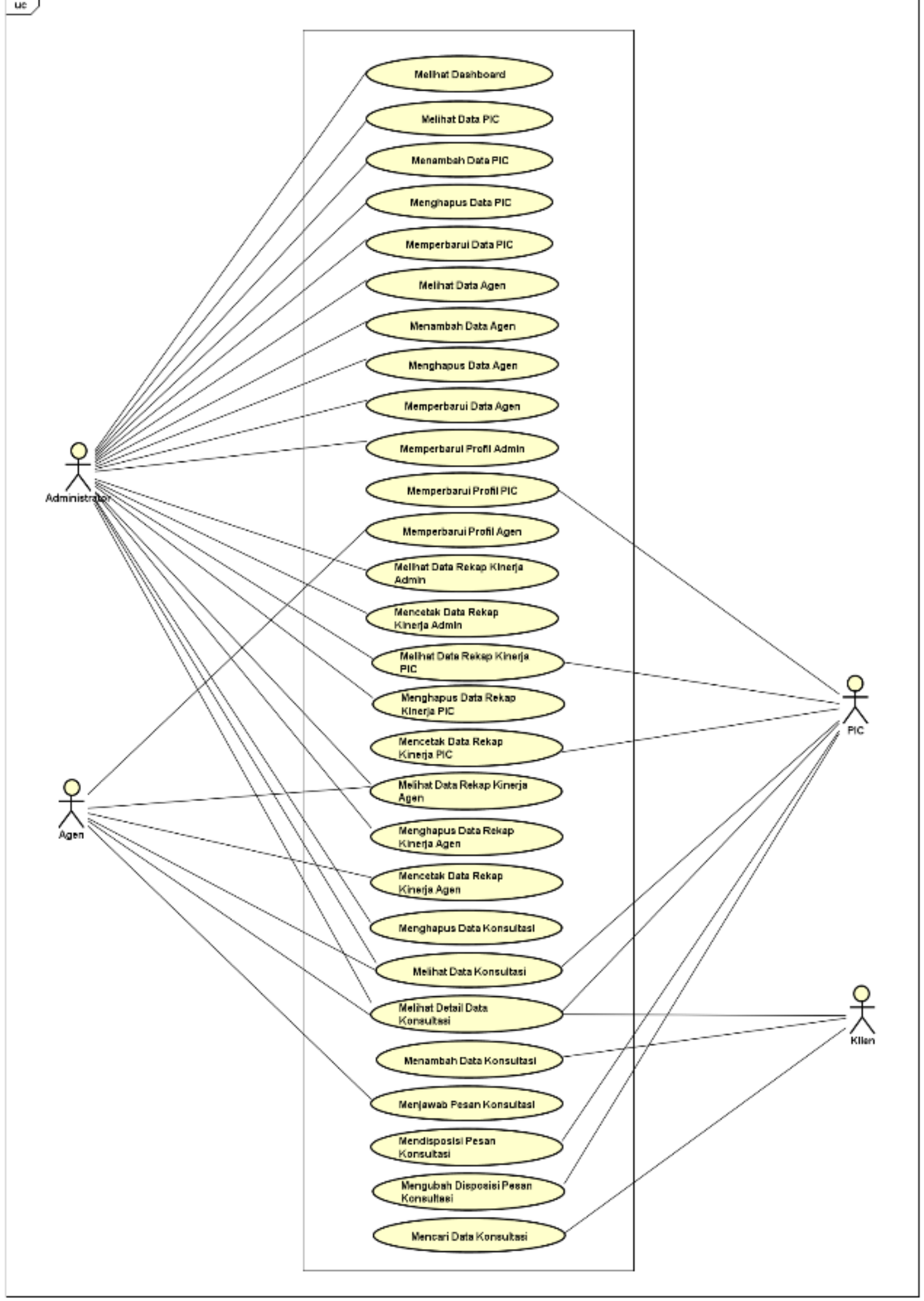

Gambar 2. Use Case Diagram Sistem E-matur 
472 Jurnal Teknologi Informasi dan Ilmu Komputer (JTIIK), Vol. 6, No. 5, Oktober 2019, hlm. 467-474

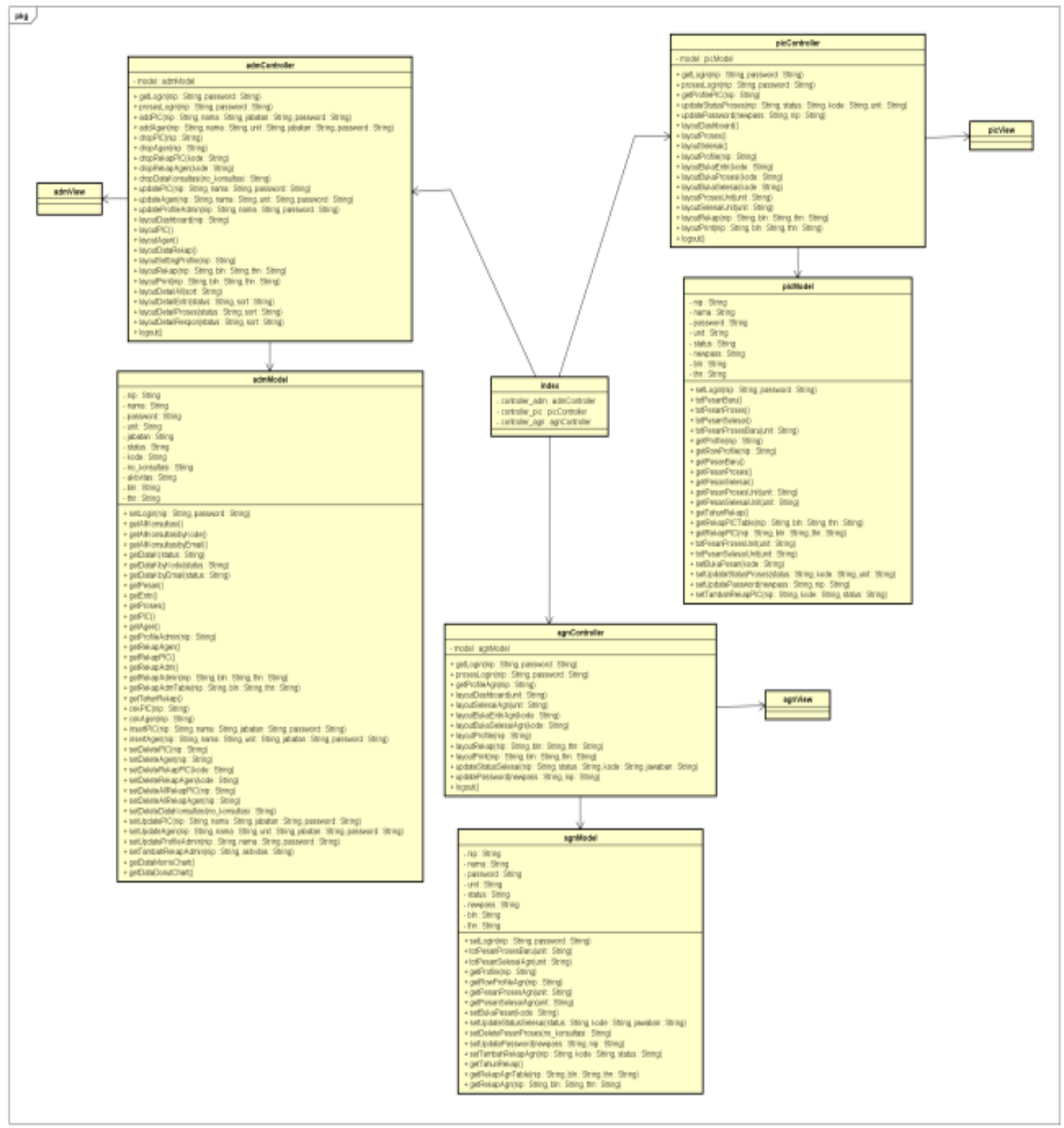

Gambar 3. Class Diagram Sistem E-matur

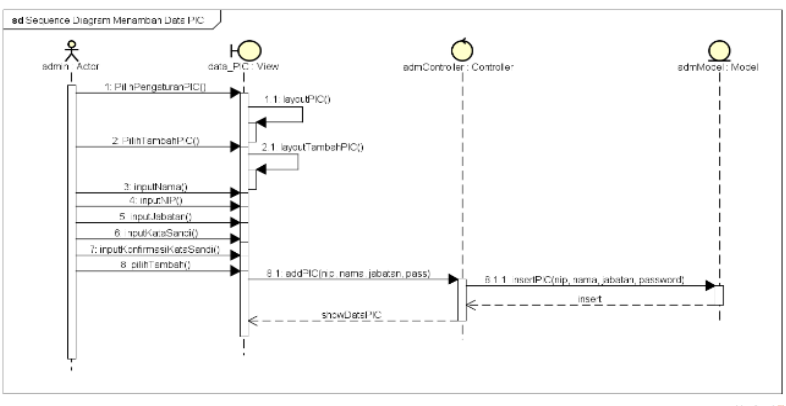

Gambar 5. Sequence Diagram Menambah Data PIC

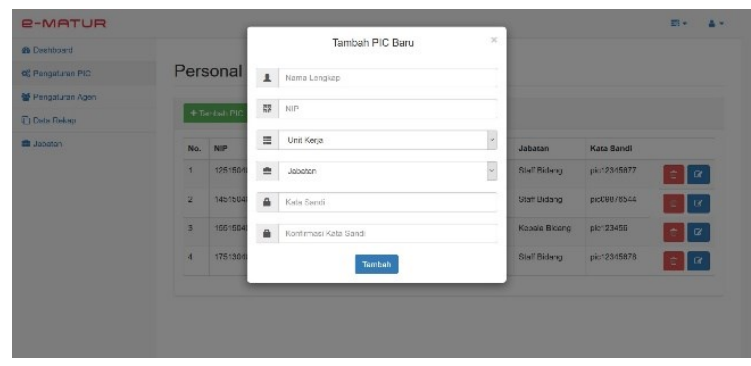

Gambar 6. Antar muka penambahan data PIC 


\section{HASIL DAN PEMBAHASAN}

\subsection{Implementasi}

Tabel 3. Kode Program

\begin{tabular}{|} 
public function insertPIC(\$nip, \$nama, \\
\$jabatan, \$password) \\
\$this->nip=\$nip; \\
\$this->nama=\$nama; \\
\$this->password=\$password; \\
\$this->jabatan=\$jabatan; \\
\$insert = \$this->mysli- \\
INTO pic (nip, nama, \\
>query("INSERT ('\$this->nip', \\
jabatan, password) VALUES '\$this->jabatan', '\$this- \\
\$this->nama', \\
>password')"); \\
return \$insert;
\end{tabular}

Hasil perancangan sistem diterjemahkan ke dalam kode program untuk melakukan implementasi sistem E-Matur. Berdasarkan perancangan sistem yang menggunakan OOAD maka implementasi sistem menggunakan pendekatan Object Oriented Programming (OOP). Hasil implementasi terdiri dari 3 subclass controller yang menggambarkan kemampuan fungsional sistem serta 3 subclass model untuk menangani basis data. Cuplikan kode untuk fungsi menambah PIC disajikan pada Tabel 3. Gambar 7 merupakan antarmuka dari implementasi sistem dalam melakukan penambahan PIC. Terdapat 6 kolom yaitu kolom Nama Lengkap, NIP, Unit Kerja, Jabatan, Kata Sandi, dan Konfirmasi Kata Sandi.

\subsection{Pengujian Sistem}

\subsubsection{Pengujian White Box}

Pengujian white box dilakukan menggunakan basis path testing untuk mengetahui kompleksitas logika (cyclomatic complexity) pada sistem (Pressman, 2010). Dalam penelitian ini, pengujian white box yang dilakukan terdiri atas pengujian unit dan pengujian integrasi.

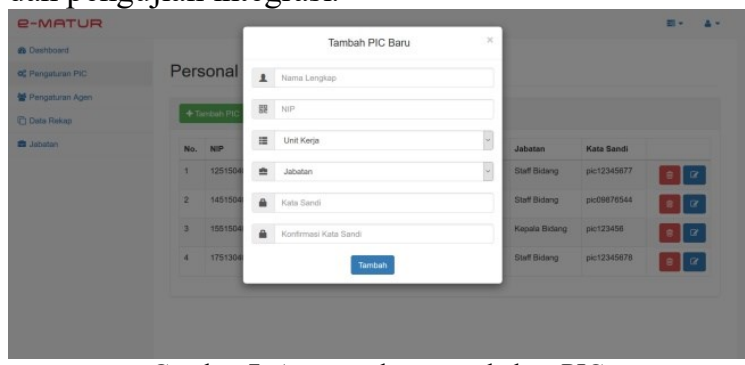

Gambar 7. Antar muka penambahan PIC

Pengujian unit dilakukan pada 1 fungsi yaitu fungsi untuk menambahkan Personal In Charge (PIC). Berdasarkan kasus uji yang dilakukan, maka didapatkan jumlah Region $=2$, Node $=11, E d g e=13$, dan Predicate Node $=3$. Sehingga nilai cycomatic complexity yang didapatkan adalah 4. Hal ini menunjukkan bahwa tingkat resiko terjadinya kesalahan program adalah rendah. Sedangkan untuk pengujian integrasi juga dilakukan pada fungsi untuk menambahkan Personal In Charge (PIC) dan didapatkan hasil pengujian yang valid.

\subsubsection{Pengujian Black Box}

Pengujian black box bertujuan untuk mengetahui apakah sistem informasi yang telah diimplementasikan sesuai dengan kebutuhan yang telah diidentifikasikan sebelumnya pada fase analisis kebutuhan. Pengujian black box dilakukan pada seluruh use case sistem E-Matur yang telah diidentifikasikan pada fase analisis kebutuhan, sehingga terdapat 28 kasus uji yang dilakukan. Berdasarkan pada 28 kasus uji, hasil pengujian menunjukkan hasil "Valid" pada seluruh kasus uji. Berikut merupakan hasil pengujian black box pada kasus penambahan Personal In Charge (PIC) yang dituangkan dalam Tabel 4.

Tabel 4. Hasil Pengujian Menambahkan Data PIC

\begin{tabular}{ll}
$\begin{array}{l}\text { Nama Kasus } \\
\text { Uji }\end{array}$ & \multicolumn{1}{c}{$\begin{array}{c}\text { Menambahkan Data Personal In } \\
\text { Charge (PIC) }\end{array}$} \\
\hline $\begin{array}{l}\text { Nomor } \\
\text { Kebutuhan }\end{array}$ & EM-F-007 \\
\hline $\begin{array}{l}\text { Tujuan } \\
\text { Pengujian }\end{array}$ & $\begin{array}{l}\text { Pengujian dilakukan untuk memastikan } \\
\text { sistem dapat menambahkan data } \\
\text { Personal In Charge (PIC) baru }\end{array}$ \\
\hline $\begin{array}{l}\text { Prosedur } \\
\text { Pengujian }\end{array}$ & $\begin{array}{l}\text { Admin memilih menu Pengaturan } \\
\text { PIC }\end{array}$ \\
& $\begin{array}{l}\text { Admin menekan tombol Tambah } \\
\text { PIC }\end{array}$ \\
& $\begin{array}{l}\text { Admin memasukkan data PIC baru } \\
\text { Admin menekan tombol Tambah }\end{array}$ \\
\hline $\begin{array}{l}\text { Hasil Yang } \\
\text { Diharapkan }\end{array}$ & $\begin{array}{l}\text { Sistem dapat menambahkan data } \\
\text { Personal In Charge (PIC) baru dan } \\
\text { menampilkan halaman data PIC setelah } \\
\text { dilakukan penambahan data. }\end{array}$ \\
\hline $\begin{array}{l}\text { Hasil } \\
\text { Pengujian }\end{array}$ & $\begin{array}{l}\text { Sistem menambahkan data Personal In } \\
\text { Charge (PIC) baru dan menampilkan } \\
\text { halaman data PIC setelah dilakukan } \\
\text { penambahan data. }\end{array}$ \\
\hline Status Validitas & Valid \\
\hline
\end{tabular}

\section{KESIMPULAN}

Berdasarkan hasil penelitian, dapat diambil beberapa simpulan, yaitu:

1. Proses perancangan sistem menghasilkan diagram use case berdasarkan kebutuhan fungsional sistem yang dilakukan pada fase architectural design. Terdapat 28 use case pada perancangan diagram use case dan setiap alur kerja sederhana dari masing-masing use case dijelaskan dalam tabel use case scenario. Alur data dalam sistem digambarkan dengan sequence diagram dan class diagram pada fase component design. Pada Class diagram terdapat 3 kelas controller dan 3 kelas model. Selanjutnya terdapat perancangan database yang digambarkan dalam diagram physical data model pada fase component design ini.

2. Proses implementasi sistem pada fase code generation menggunakan PHP sebagai bahasa pemrograman dan MySQL sebagai manajemen 
basis data. Implementasi sistem menghasilkan penjelasan deskriptif mengenai fungsi dan potongan program yang diimplementasikan beserta screenshot tampilan dari setiap halaman sistem yang menggambarkan kode program yang diimpementasikan.

3. Proses pengujian yang dilakukan meliputi unit testing, integration testing, system testing, dan acceptance testing. Unit testing dilakukan menggunakan basis path testing dan menghasilkan 4 independent path melalui perhitungan cyclomatic complexity pada kasus uji unit addPIC. Integration testing pada kasus uji fungsi addPIC dari class controller admController dengan fungsi insertPIC dari class model admModel menunjukkan hasil valid. System testing dilakukan terhadap 28 fungsi sistem dan menunjukkan hasil yang valid. Acceptance testing yang dilakukan terhadap stakeholder atau user dengan menggunakan black box testing menunjukkan bahwa stakeholder telah menerima fungsi yang dibangun dan telah sesuai dengan kebutuhan fungsional pada dokumen elisitasi kebutuhan sistem.

\section{DAFTAR PUSTAKA}

HANDOKO, W.T., LESTARININGSIH, E., \& ARDHIANTO, E, 2014. Rancang Bangun Sistem Informasi Data Konsultasi Perkara Klien Pada Biro Konsultasi Dan Bantuan Hukum (BKBH) Universitas Stikubank (UNISBANK) Semarang. Jurnal Dinamika Informatika, 6(1), p.17-26.

NURBAITY, S., 2010. Pengembangan Sistem Informasi Kepegawaian (SIMPEG) Berbasis Web (Studi Kasus: Subbag Useristrasi Kepegawaian Pusat UIN Syarif Hidayatullah Jakarta). Universitas Islam Negeri Syarif Hidayatullah.PRESSMAN, R.S. 2010. Software Engineering $A$ Practitioner's Approach, Seventh Edition. New York: McGraw-Hill.

TURBAN, E. \& VOLONINO, L., 2011. Information Technology for Management Improving Strategic and Operational Performance. New York: John Wiley \& Sons, Inc.

WINGATE, L.M., 2015. Projrct Management for Research and Development: Guiding Innovation for positive R\&D Outcomes. Norwegia: CRC Press. 